\title{
The Meaning of Signs in Balia Spell of Kaili Ethnic in Palu
}

\author{
Agustan* Setya Yuwana Sudikan Budinuryanta Yohanes \\ The State University of Surabaya, Surabaya, Indonesia
}

\begin{abstract}
This research aimed to find the meaning of the signs in Balia spells of Kaili ethnic in Palu. It used metapragmasemiotik theory, which is a combination of metalinguistic, pragmatic, and semiotic theories. This research is descriptive qualitative approach. The source of the spell treatment is the text. The data collection is through recording, transcription, and transliteration. The data analysis technique used objective hermeneutics which is divided into two procedures namely (1) sequential analysis and (2) detailed analysis. The findings of this study are the sign meanings in Balia spells of Kaili ethnic in Palu, namely (1) narrowed meaning, (2) broad meaning, (3) cognitive meaning, (4) emotive meaning, (5) referential meaning, (6) grammatical meaning, (7) idional meaning, and (8) idiomatic meaning. Theoretically, this study strengthens pragmatics and semiotics because the findings of this study indicate that the meaning of the sign in the Balia ritual spells is generated from verbal signs, namely speech. Practically, this finding is useful for universities related to the teaching of oral literature that develops interdisciplinary science by integrating three theories for one study namely metalinguistic, pragmatic, and semiotics.
\end{abstract}

Keywords: meaning, signs, spells, Balia.

DOI: $10.7176 /$ RHSS/10-6-08

Publication date:March $31^{\text {st }} 2020$

\section{Introduction}

Balia is a non-medical treatment ceremony prior to the existence of medical science which is a Kaili ethnic tradition in Palu, Central Sulawesi. Previously, this ceremony relied on the community to get guidance and ancestral assistance in curing certain diseases. In the process of treatment through Balia, a Sando nuBalia (the shaman of Balia) recites spells, called ganes, as the requirement in the treatment process. Based on the search, there were four types of spells in Balia, namely the initial spell (gane pamula), middle spell (gane tongo), final spell (gane panggaopu), and earth spell (gane lino). Inside of those spells, there are signs that have different meanings. The meaning of the sign in Balia spells will be described based on the opinion of several experts namely Bloomfield (1933), Ullman (1962), Palmer (1976), Verhaar (1981), and Kridalaksana (1984). The types of meanings include (1) narrow meanings, (2) broad meanings, (3) cognitive meanings, (4) emotive meanings, (5) referential meanings, (6) grammatical meanings, (7) idional meanings, and (8) idiomatic meaning.

Bloomfield (Djajasudarma, 2016: 8) argues that the narrowed meaning is a meaning that is narrower than the whole utterance. Meaning which origin is wider can be narrowed because it is limited. Extended meaning is the meaning inside of a word which is wider than expected. Cognitive meaning can be called descriptive or denotative meaning is the meaning that indicates the relationship between the concept and the world of reality or it can also be called straightforward meaning, as it is. Other meanings which are the same as cognitive meanings are referential meanings. It is a meanings that are directly related to reality or referents. Equated with cognitive meaning because it has a reference. It also has a relationship with the concept of something that has become an agreement by the language user community.

The connotative meaning and emotive meaning are distinguished by the taste that arises due to the association of feelings towards the thing said or heard. The connotative meaning can be said as a negative meaning, while the emotive meaning can be called a positive meaning. In addition, there is a construction meaning which can also be called the meaning of property or which is inside of the construction or which shows it belongs.

The common meaning is lexical and grammatical meaning. It is called lexical meaning because it constitute the meaning of the language elements as a symbol of objects and events which are apart from the context (dictionary meanings), permanent and not bound by other words or independence. While the grammatical meaning, it is the meaning that involves intrangual relations, or the meaning that arises as a result of the functioning of a word in a sentence, or the meaning that changes according to the context of the user. This happens due to the grammatical processes that occur in the word, such as affixing, repetition, and compounding.

Idesional meaning and the proposition meaning are two meanings that synergize each other. Idesional meaning which is the meaning of concepts or ideas contained in words. It can be the proposition meaning as the meaning of the ideas embodiment that contain suggestions, things that lead to the target, and plans through context.

Idiomatic meaning is a lexical meaning that is formed from several words that are usually obtained in expressions and proverbs, words arranged in combination with other words which can also produce different meanings. There are also so-called central meanings which are the meanings that each word has at the core of the utterance. Each utterance (clause, sentence, discourse) has a meaning which becomes the center (core) of the 
conversation. The central meaning is also called a meaningless character because it can be presented or not presented in the context.

Leech (1974) divides the types of meaning into three parts, namely conceptual meaning, associative meaning, and thematic meaning. Included in the associative meaning are connotative meanings, stylistic meanings, affective meanings, reflective meanings, and collocative meanings. Regarding with the meaning of a word that is related to the feelings of the listener or reader is called pictorial meaning.

This research is based on research from experts such as Silverstein, Duranti, Derrida, Urban, Staehr, Verschueren, Hjelmslev, Fernández, Blunk, and Alatas who have conducted several studies on the meaning of signs. The research of Urban (2006) on metasemiotics is a series of development of the Peirce sign trichotomy hierarchy concept which includes icons, indices, and symbols which are closely related to symbol studies and context studies by Silverstein on the discourse of semiosis and metapragmatics related to context.

The meaning of the signs in the Balia spells is closely related to social and cultural phenomena as well as the metalinguistic and metacognitive viewpoints of the Balia perpetrators. The signs in the spells are formed from sociocultural and supernatural processes, individually and communally. Signs in individual spells can occur when reciting a spell. The sign can be in the form of codes from the language spoken, or in the form of symbols from the expression of a spell person (someone who did spells). Whereas the spells formed communally are produced by groups of Balia ritual performers who carry out the marking activities when reciting spells.

Signs basically are all things that can be used as signifier and as siginified). In this case,the signifier is a symbol that serves to explain the marker as the meaning. Saussure defines semiotics as the study of the role of signs as part of social life. This opinion is in line with the concept of signs developed by Peirce in the form of metatanda which later became known as trichotomy; icons, indexes and symbols. In Balia ritual, this concept is a new thought as a collaborative semiotic and pragmatic concept focused on the transformation of signs. Those arise due to the influence of other sociocultural aspects which then bring up sign categories in the form, meaning and function.

The concept of the Saussure sign as an inseparable unity between the signifier and the signified and its relationship to the Peirce trichotomy metatanda, is closely related to the significance of semiotic thinking. It also related to the communication semiotics in viewing the sign as a unified form that is flexible in its context. This is in line with Saussure's thought as a pioneer of the concept that social conventions in the language community function concretely to regulate the meaning of a sign (Fiske, 1990: 15). This opinion supports Culler's thought that one word has a certain meaning due to a social agreement among the language user community (Culler, $1976: 19$

The development study of the Saussure sign mentioned by Fiske (1990: 15). It is shown that semiotics is the study of the role of signs as part of social life. From this opinion, it can be concluded that the sign is a relation that is part of social life and rules that are applicable. The social convention referred by Saussure is a sign system and social systems that are interconnected. This thinking is the development of the concept of unity of form and meaning, namely signifier and signified that can be synchronized with the development of Peirce's thought.

Peirce's concept of trichotomy is an empirical study of the development of semiotics into metasemiotics. His rationale was also influenced by Kant's exploration. Peirce views the ability of humans to relate with external reality as a result of a complex process of layered signs in the form of icons, indices, and symbols (Urban, 2006: 89).

\section{Research Method}

This study was qualitative research with a realistic ethnographic approach, namely research conducted on certain cultural groups for a long time to obtain data naturally without taking sides with the research subjects (Creswell, 2014: ix). The research data which is in the form of Balia spells were obtained from seven informants, they are the Kaili ethnic group, aged 46 years to 78 years. Data collection is done by (1) observation, (2) in-depth interviews, and (3) recording. The data collected were analyzed by an objective hermeneutic model divided by two procedures namely series analysis and detailed analysis. Sequential analysis is to select and break up text into smaller units and interpret it to find clarity of meaning contained in the text. Detailed analysis is to divide the text sequentially and fragmented into sub-chapters and then interpreted to find meaning contextually by considering internal and external meanings (Ibrahim, 2009, p.233-234).

\section{Findings and Discussion}

Findings discussed from the results of this reseaech are found in the initial spell, middle spell, final spell, and earth spell including (1) narrowed meaning, (2) broad meaning, (3) cognitive meaning, (4) ) emotive meaning, (5) referential meaning, (6) grammatical meaning, (7) idesional meaning, and (8) idiomatic meaning which are described as follows.

3.1 Narrowed meaning, found in array:

(a) E anitu ante langgara, kamaimo ruru sipuramo kandea miu mpengana 
(O great ancestors and great shamans, these are all foods that are served to you)

The meaning of the candea array (food) is various offerings. The meaning is narrowed only for Anitu and Langgara, not intended for all Balia players. The offerings are divided into two forms, namely those which are only decorated as a spells, and those in the form of food to be eaten together after the Balia procession takes place. The narrative of Anitu and Langgara arrays by Sando nu Balia is a narrow meaning that is categorized as a special sign contained in the array of spells. Miu or komiu leksem is interpreted as you or a substitute for Anitu and Langgara. Miu is not meant as a subject present (in general), but is specifically enforced

(b) E anitu vali, tabe ruru yaku

(O great ancestor, excuse me first)

The yaku (me) array is a sign of narrow meaning because it appoints Sando nu Balia (dukun Balia) personally as the leader of the treatment ceremony. Anitu (great ancestor) also means narrow because it refers to personal, not communal. Lari Anitu and Yaku are in a position of narrow meanings that are parallel and associative but experience symptoms that cannot be generalized. Anitu is an abstract great ancestral personality, while yaku is a real Sando nu Balia (shaman Balia) personality.

(c) E Karampua ri vala-vala

(Wahai, penghuni tempat Balia)

(Oh, residents of Balia)

The meaning of Karampua's array is contradicted by its translation as a dweller which can be interpreted as an embodiment of people. The interpretation of its meaning can be generalized. But in this array, karampua has a special meaning because it referred to only those who are involved in rituals that are in the vala-vala. It means limited small space. The naming of vala-vala as a room also means narrow and is a sign that represents a space that is limited to the place where the ceremony is held.

3.2 Broad meaning, found in arrays:

(a) E Tupu tabe ruru kami

(O Lord, excuse us first)

The word "us/we" means broad or general because it signifies all followers of Balia. It is also interpreted as a society or humanity. We/us in the Balia spellss are polite words that indicate plural, broad and global.

(b) E Rampo sende rae kami nengoimo

$(\mathrm{O}$, in the call of the heart, we complain)

The array of kami nengoimo is broadly meaningful, interpreted as all users of Balia, children and grandchildren and all their offspring. There is a Sando nu Balia interprets kami nengoimo as human in general, or humanity. Kami nengoimo (which means we complain) means the act of complaining together so that it can be categorized as a sign that has broad meaning.

(c) E kami mabunto nggoro domoraya mbulu

(O we sinned, but not sick)

Kami mabunto (we sinned) is a sign of a broad category of meaning. This array does not specifically mention the sin that is committed or which act causes the sin, or the form of the act which causes the sin and the type of small sin or great sin. So it is categorized as a broad meaning. It is similar with domoraya mbulu array (but not sick).It also does not mention the type of illness that is suffered specifically. Disease in this array can be interpreted as physical or mental illness.

(d) E karampua ri tana, karampua ri lino.

(O inhabitants of the earth, inhabitants of the world)

This array of spells shows its broad meaning, because it mentions the inhabitants of the earth. Inhabitants of the earth means general. In the Balia spell array, a lot of array mention the words ri tana and ri lino which can be associated with the spell's form as an inconic sin sign which can change its shape because it shows similarity or parallel. Meanwhile, in the real meaning of the sign is different and can be included in the rheme category. It can change its form and give rise to different thoughts. Ri tana is interpreted as earth, and ri lino is meant as world. In the meaning of ri tana or earth, Sando nu Balia and the performer of Balia believe that this array of spells is intended for ordinary people. On the other hand, the meaning of ri lino or the world is believed to be an array intended for the inhabitants of the middle world or middle nature, known as laerava.

3.3 Cognitive meaning, found in arrays:

(a) E Tupu ala taala, merapi ampu, tulungi riambonggadata

(O God, the power, we beg for forgiveness and help, we are helpless servants)

Straightly, the array of this spell means a request to God to be given help, and an acknowledgment of the limitations and helplessness of humans so that they need the help of God Almighty. This straightforward meaning is seen in a series of arrays that are not ambiguous and not connotative. The word merapi ampu (forgiveness) can be interpreted as denotative as part of cognitive understanding. Apologies are not a figurative, but are realized as 
concrete signs, not abstract signs.

(b) E masintuvu, maliuntinuvu sampa pitu sangganuvu

(Oh, let's get together, live a life, live a long life, be strong, physically and mentally healthy)

The meaning of this array can be understood straightforwardly, about inviting each other to the goodness, loyalty, happy life physically and mentally. It is realistic and explain the meaning of praying for one another so that long life and strength. It generally is intended for young people so that all can be maintained health and free from various physical and mental illnesses

(c) E Langgara ante toboti ri laerava, e ranga nalentoramo kami apa nasaemo le nasua

$(\mathrm{O}$, great shaman and the couple of 'bridegroom 'in the middle of the universe, oh dear, we have missed because it's been quite a long time).

This array means straightforward, said as an expression of the longing of Sando nu Balia who had not met the ancestors and relatives who had come to join Balia. In the array e langgara ante toboti ri laerava, it is kind of a figurative type, but straightforward because in the context this array is intended for the great shaman who is metacognitively in the mind of the performer. This straightforward meaning is not equated with denotative meaning, but it is at the level of contextual speakers who interpret openly.

3.4 Emotive meaning, found in arrays:

(a) Anitu ri langi, ane motombale iko, pegoli potuobo petiro yaku

(Great ancestors in the sky, if you face the sky, you face back down look at me)

The emotive meaning contained in the spell array is to remind that when someone's position is above or successful, rich, they must not forget the people below and still care for the poor. Ane motombale iko array emotionally implies to not forgetting oneself at the top,always look back down. When we are enough in material sufficiency, keep living simple, do not arrogant, and care for another people.

(b) E Karampua ri tana, ane motuobo iko, pegoli potumbale tingoa yaku

(O people of the earth, if you face down, you face up and see me)

Array of this spell means emotive reminiscent of the balance of nature and life. It means that when we are in under (in poor condition), in order to progress then once in a while we have to look up and used it as motivation in life so that we are able to achieve success. When you are in above (in rich condition), and well-off, don't forget the life when it's hard. This balance teaching is an essence of Balia spell which contains advice for generations.

(c) E kamaimo kita mompetiro

(O, let us look from the top down)

The array of this spell means an invitation to care for one another, especially those who cannot afford the economy or the poor. This array of spells is emotive, reminding each other so that when we are victorious, do not forget the little people (not in rich condition). It is because of their services and assistance so that the glory can be obtained. E kamaimo kita mompetiro can be interpreted emotively to be a sensitive person to social phenomena, maintaining good relations between people.

(d) E Anitu ante Langgara ri laerava mpedua inja-inja komi

(O great grandfather and great shaman in the middle of the world, who else enters this?)

This array of spells is emotive, a dialogue takes place between Sando nu Balia and ancestors in the natural world. Sando nu Balia wanted to convince himself that this treatment was not interfered by ancestors who were not allowed to come. In the procession of Balia, only the ancestors which is mentioned by name are invited to come. If another ancestor arrives, it will be detected by him who is on duty with the pila-pila nu Balia or supporters who are invited to attend.

3.5 Referential meaning, found in arrays:

(a) E ribati gala kuendeka komi

(Dear, we have offered the chicken)

The array of spells is said based on the reference that the chicken has been offered significantly during the treatment procession. A rooster is tied to a central pole made of hard wood. Referentially the chicken is bound to the pole and is spoken in a spell.

(b) E Anitu ria rampa konoimo komi

(O great grandfather, we feed you)

This array of spell is a symbol of the great ancestors who will not eat food that is presented. Meanwhile, in Balia rituals, offerings in the form of a variety of foods are still manifested as items required for medical ceremonies. If the conditions are not met then it will have a negative impact on the executor of the Balia.

(c) E langgara ri laerava hi vua koyana mompinonggo kami

(O great shaman in the middle of the universe, this is the betel fruit you use)

This spell array means the manifestation of betel fruit as a condition that must be fulfilled when the Balia ritual is held. Betel fruit is a sign that is realized, although symbolically the betel fruit displays an understanding of respect 
for a purified business.

3.6 Grammatical meaning, found in arrays:

(a) E Langgara mpedua pouluka danda

(O great shaman, let me ride first)

The 'ride' array in this spell is a sign that is grammatically meaning, because the array is lexically more appropriate if used for vehicles or objects that can be used as a ride. Grammatically in the context of the spell, it means as words that have supernatural powers. The word 'I ride' means to want help to solve a problem that cannot be solved alone.

(b) E Anitu ria rampa konoimo komi

(O great grandfather, we feed you)

This array means the word 'eat' is not to be eaten by the great ancestors, but the food or offerings provided are only a symbol. The offerings as nonverbal signs are still spoken in spells so that in text and contextual terms, they are still manifested in their grammatical meaning, contained in the array of spells

(c) E Tuputaala, ria somba-somba konoimo komi, kami aga pale ntovea

(O powerful, this is a worship offering only to you, because our hands are weak)

The meaning of this spell array is the grammatical meaning which indicates that our hands are weak. Meanwhile, the real meaning is limitations and helplessness.

3.7 Idesional meaning, found in arrays:

(a) E Langgara ri laerava, ntade ntanialeva, petiro kami

(O great shamans in the midst, we are serious, we need shelter)

This array contains the meaning of the professional sign contained in the word Langgara ri laerava ndate ntanialeva (great shaman), conceptually there is a great shaman who will be a connector with the natural world to find out the disease suffered and what solutions will be done to overcome the disease. Similarly, the word laerava when spoken in a spell. The concept arises is the middle of nature. It means the place where the ancestors resided. In petiro kami (see us) array, it means 'in the middle of nature and we need shelter.'

(b) E eimo nun-mbiroe mololo mpotaba

$(\mathrm{O}$, there is the blue nunu, banyan tree with leaf buds)

The array of blue пипи spells means that is believed and established by supporters of Balia as the exit and entry of ancestors from the mortal world to the 'among world'. In the original text, the spell array does not mention blue nunu, only mentions a banyan tree which cannot be categorized as an idesional meaning. After the array of spells has changed, it is called the blue nunu which is believed by Sando nu Balia as the gate of the sky or the entrance and exit from the natural world to 'among world'. Another interpretation based on the array of spells, the professional blue nunu array exists in the human body that is between the fontanel to the liver, heart, out through the toenails, and that can only be opened by Sando nu Balia (shaman Balia), cannot be done by Sando to Lino (world shaman).

3.8 Idiomatic meaning, found in arrays:

(a) E masintuvu kita maroso, morambanga kita marisi

(O united, we are sturdy, together we are strong)

This array contains idiomatic sign meanings which are expressions of local proverbs that are included in spells and contain meanings of invitation to unite to be sturdy and to be strong together. This idiom raises the meaning of the Kaili ethnic locality which upholds local wisdom which is reflected in the lines of the Balia spell.

(b) E Mantepunggu raala do mabunto

$(\mathrm{O}$, taken bound, not condemned or harmed)

This line of spells is also an expression that contains the Kaili ethnic idiom meaning which indicates that by pursuing clean intentions with the ties of custom and religion, ancestors will be favored, and will not be condemned and harmed.

(c) Sanggani, Allah taala sangu nakuasa.

(Once, Allah subhanawataala the one that is power)

This array spells are idiomatic of Kaili numbers as the first count that is connected with the meaning of the word sanggani, Allah taala sangu nasaasa. This idiomatic meaning arises because of the existence of a verification function that connects the word sanggani (one time) with an array of Sanggani , Allah taala sangu nasaasa which is the basic idea of the arrangement of expressive spells that recognizes only Allah Subhanawataalah who has the power.

(d) Papitu Maliuntinuvu, eva kuni botoila

(Seven feel grateful to God, like turmeric and whiting)

The meaning of the papitunggani to be the papali maliuntinuvu, eva kuni botoila is an idiomatic meaning, because 
this array is absorbed from local Kaili ethnic principles whose meaning at number seven as an odd number that is praised by Balia performers. Likewise eva kuni botoila array (such as turmeric and whiting) symbolizes the interrelated symbol that forms the meaning that has become the grip on local Kaili, the seventh count is the final count that indicates the maximum signification occurs.

\section{Conclussion}

The research on the meaning of signs in the Kaili ethnic Balia spell in Palu found eight types of sign meanings namely (1) three arrays of the narrowed meaning, (2) four arrays of the broad meaning, (3) three arrays of the cognitive meaning, (4) four arrays of the emotive meaning, ( 5) three arrays of referential meaning, (6) three arrays of grammatical meaning, (7) two arrays of idesional meanings, and (8) four arrays of idiomatic meanings.

\section{References}

Cummings, Louise. (2007), Pragmatik. Sebuah Perspektif Multidisiplin. Diterjemahkan oleh Eti Setiawati, dkk. Yogyakarata: Pustaka Pelajar.

Creswell, John W. (2014), Penelitian Kualitatif dan Desain Riset. Memilih di antara Lima Pendekatan. Alih bahasa oleh Ahmad Lintang Lazuardi.Yogyakarta: PustakaPelajar.

Djajasudarma, F. (2016), Semantik 2. Bandung: Refika Aditama

Kaelan (2009), Filsafat Bahasa Semiotika dam Hermeneutika. Yogjakarta: Paradigma

Levinson C, Gumperz J. (1996) Rethinking Linguistic Relativity. Cambridge University Press

Misna (2010), Mengenal Kebudayaan Balia, Palu-Sulawesi Tengah: Quanta Press

Masyhuda, M. (1983), Ritual Balia di Sulawesi Tengah. Palu: Yayasan Kebudayaan Sulawesi Tengah Seksi Penerbitan.

Nazriani (2013), "Mantra Dalam Upacara Pesondo : Kajian Struktur Teks, Konteks Penuturan, Proses Penciptaan, Fungsi, dan Pemanfaatannya sebagai Bahan Bahan Ajar Sastra Di SMA”.@rtikulasi Jurnal Kajian Bahasa dan Sastra Indonesia. Vol.12, No.2, Nov. 2013.

Nadar, F.X. (2013), Pragmatik dan Penelitian Pragmatik. Yogyakarta: Graha Ilmu.

Pateda, Mansur (2001), Semantik Leksikal. Jakarta: Rineka Cipta

Putrayasa, I.B. (2014), Pragmatik. Yogyakarta: Graha Ilmu

Pujileksono, S. (2015), Pengantar Antropologi, Memahami Realitas Sosial Budaya. Malang: Intrans Publishing Peirce (1991), Peirce on Signs: Writing on Semiotic, New Edition. USA: The University of North Carolina Press. Rusmana, Dadan (2014), Filsafat Semiotika. Bandung: Pustaka Setia

Silverstein, Michael (1993), “Metapragmatic discourse and metapragmatic function”. In John A. Lucy (ed), pp. 33-58.

Skilleas, Martin (2001), Philosophy and Literature an Introduction. Edinburgh University Press

Silverstein, Michael (2001), "Batas Kesadaran," dalam Antropologi Linguistik: Seorang Pembaca. Diedit oleh A. Duranti, Malden: Blackwell. 382-401.

Thomas, J. (1995), Meaning in Interaction: An Introduction to Pragmatics. New York: Longman.

Urban, G. (2006), Metasemiosis and Metapragmatics. Philadelphia: University of Pennsylvania.

Yule, George. (2014), Pragmatik. Diterjemahkan oleh Indah Fajar Wahyuni. Yogyakarta: Pustaka Pelajar. 